\title{
INDONESIAN FROZEN AND PROCESSED CRAB EXPORT PERFORMANCE AND COMPETITIVENESS ANALYSIS
}

\author{
Uswatun Khasanah $^{1}$, Wen-Chi Huang ${ }^{2}$, Rosihan Asmara ${ }^{3}$ \\ ${ }^{1}$ Double Degree Program in Faculty of Agriculture, Brawijaya University, Indonesia and National Pingtung \\ University of Science and Technology, Taiwan \\ ${ }^{2}$ National Pingtung University of Science and Technology, Taiwan \\ ${ }^{3}$ Faculty of Agriculture, Brawijaya University, Indonesia \\ *corresponding author: uuskhasanah99@gmail.com
}

\begin{abstract}
This paper aimed to analyze the performance and competitiveness of Indonesian crabs in the international market by comparing it with other major crab export countries (China, Philippines, Vietnam and Korea). Two crab products were included in the study, namely processed crabs in cans (HS 160510) and frozen crabs (HS 030614). The Trade Balance Index (TBI), Normalized Revealed Comparative Advantage (NRCA), and the Comparative Export Index (CEP) were used by analyzing data from the Central Statistics Agency (BPS), Ministry of Maritime Affairs and Fisheries (KKP) in Indonesia as well as from UN COMTRADE, and Trade Map. The results based on TBI that the processed crabs were at the maturity stage, while the frozen crabs were at the growth stage. Only processed crab products had CEP values above 1, which means Indonesia is specialized and more competitive in processed crab products.
\end{abstract}

Keywords: Frozen Crab, Crab in cans, Trade Performance, Comparative advantage

http://dx.doi.org/10.21776/ub.agrise.2019.019.3.5

Received 09 July 2019

Accepted 30 July 2019

Available online 25 August 2019

\section{INTRODUCTION}

Indonesia's natural resources from the marine sector are very potential in terms of quality and quantity. It can be seen from the cultivation fisheries production from 1999-2016 that there is always increase. Opportunities for developing Indonesian fisheries have very high prospect, because resources in the fisheries sector are an important for people's livelihoods and have the potential to be the prime mover of the national economy. Not only able to cover domestic needs but also able to meet international market demand (BPS, 2019).

$\mathrm{Crab}$ is one of important fishery export commodities of Indonesia. In 2017, crab was the first biggest export value of Indonesia, the second is shrimp and the third is tuna (KKP, 2019). Crab (Scylla serrata) and (Portunus pelagicus) have become the mainstay commodities of Indonesian exports to various countries in the world. Crab is one of the commodities specifically mentioned in the Indonesian fisheries statistics published by the Ministry of Maritime Affairs and Fisheries of the Republic of Indonesia in addition to commodities of shrimp, tuna, cob and skipjack. This mention shows the important position of crabs in the Indonesian fisheries sector because of the large volume and value of exports produced and quite a lot of people involved in the crab industry. The 2014 Fisheries Improvement Program report that the industry involved around 65,000 fishermen and 13,000 crabs and thousands of other workers who 
were indirectly involved in this industry (Supartono, 2013).

Growth of export value in 2016-2017, shrimp is Indonesia's most successful fishery product after that TTC or Cakalang tuna take second place and crabs are in third position. The highest increase in export value was crabs by $27.8 \%$, while other trades fell by $10.03 \%$. Crab takes the top position after shrimp and TTC shows that crabs have high export potential because Indonesia as a maritime country with extensive competitive regions can produce high-quality crabs. Crabs are the most significant among the others. Increasing the volume of Indonesian crab export supply will affect Indonesia's growth, and increase Indonesia's foreign exchange. For this reason, it is necessary to know the factors that will affect the demand for commodity exports of crabs in the international market.

The top 3 main destinations in crab exports include the United States, China, Hong Kong. While competing top 3 countries are Vietnam, Philippines, Korea. Even though Indonesia has the competitiveness of crab exports, there are some whose values are below competing countries (BPS, 2019).

This study used two codes for the crab products: the first is frozen crab (HS 303614) and the second is processed crabs in cans (HS 160510).
The issue of export performance of Indonesian crabs is investigated in this study.

\section{RESEARCH METHODS}

This study uses annual time series data for 18 years, from 2000 to 2017. The data analyzed consisted of export volume, the exports value, and imports of frozen crabs (HS 030614) and processed crabs in cans (HS 160510) of main exporter countries (Indonesia, Philippines, Vietnam, China, Korea).

Data sources were obtained from the Central Statistics Agency (BPS), Cultivation Fisheries Statistics (Directorate General of Aquaculture, KKP), United Nation Commodity Trade (UN COMTRADE), Trade Map / ITC, Trading Economics, Ministry of Trade, Bank Indonesia and other agencies.

This study uses the quantitative method with the Normalized Revealed Comparative Advantage (NRCA) approach is used to analyze comparative advantage and to find out whether these specialized commodities are analyzed by the Export Performance Comparative (CEP) Index, to analyze the performance of crab product exports using the Trade Balance Index (TBI). Data used and analysis show in Table 1.

Table 1. Data and analysis

\begin{tabular}{|c|c|c|c|}
\hline Objective & Data Type & Data analysis & Output \\
\hline $\begin{array}{l}\text { Analyzing the performance } \\
\text { of exports of Indonesian } \\
\text { crab products on the } \\
\text { international market }\end{array}$ & $\begin{array}{l}\text { Data on export and } \\
\text { import of crab } \\
\text { products from 2000- } \\
2017\end{array}$ & $\begin{array}{l}\text { Trade Balance } \\
\text { Index (TBI) }\end{array}$ & $\begin{array}{l}\text { The trading position of } \\
\text { Indonesian crab products }\end{array}$ \\
\hline $\begin{array}{l}\text { Analyze the competitiveness } \\
\text { through a comparative } \\
\text { advantage approach }\end{array}$ & $\begin{array}{l}\text { Data on Indonesia's } \\
\text { total crab exports and } \\
\text { in } 2000-2017\end{array}$ & $\begin{array}{l}\text { Normalized Revealed } \\
\text { Comparative } \\
\text { Advantage (NRCA). } \\
\text { Comparative Export } \\
\text { Performance (CEP) }\end{array}$ & $\begin{array}{l}\text { The NRCA value of } \\
\text { Indonesian crab products } \\
\text { in international markets } \\
\text { indicates market share, and } \\
\text { CEP to know } \\
\text { specialization product }\end{array}$ \\
\hline
\end{tabular}

\section{Normalized Revealed Comparative Advantage (NRCA)}

This study, the modified RCA method is Normalized Revealed Comparative Advantage (NRCA) where this method has several advantages including the ability of comparability between space and time, where the addition of NRCA is stable and equal to zero between time and space and stable at the flat. This explains the meaning of the zero-sum imbedded in comparative advantage: if a country gains comparative advantage in one sector, the country will experience a loss of 
Indonesian Frozen and Processed Crab Export Performance and Competitiveness Analysis

comparative advantage in other sectors; and if one country gains a comparative advantage in one sector, then another country will suffer a comparative advantage in the same sector. NRCA has the following formula:

$$
N R C A=\frac{\Delta X i j}{X w}=\frac{X i j}{X w}-\frac{X w \mathrm{Xi}}{X w X w}
$$

Where $X$ represents the export value, index $i$, $w$, and $\mathrm{j}$ each shows the aggregate of exports at the state, regional or world level, and commodities. The range of NRCA values is $(-0.25)-(0.25)$ with Comparative Advantage Neutral (CAN) being zero. As an illustration, $-0.25<\mathrm{NRCA} i j<0$ indicates that the actual export of country $i$ for commodity $j$ is lower than the comparative advantage-neutral point, while $0<\mathrm{NRCA} i j<0.25$ indicates that country $i$ has a comparative advantage in commodity exports $j$ (Faridah, 2016).

\section{Comperative Export Performance (CEP)}

To evaluate a country's export specialization for a particular product, it is calculated using the Comparative Export Performance (CEP). If a country has a CEP value greater than one, the country has a relative advantage in its exports. Fortunately, the formula used is calculated as follows:

$$
C E P=\ln \left(\frac{X i j}{X j}\right) /\left(\frac{X i A}{X A}\right)
$$

Where: $X_{i j}$ is the export value of the country's crab commodity $j$ (US $\$$ ), $\mathrm{X} j$ is the Value of Total Country Exports $j, \mathrm{X} i A$ is the Value of Total World Export of crab commodity, $\mathrm{X} A$ is the Value of Total World Export, State $j$ includes 1) Indonesia, 2) Philippines 3) China, 4) Korea 5) Vietnam as for the Total World Exports it is only limited to the scope of Asia which is represented by only four countries, namely Indonesia, the Philippines, China, Korea, Vietnam.

\section{Trade Balance Index (TBI)}

TBI is a measure used to analyze the position or stage of development of a product so that it can be seen the tendency of a country as an exporter or importer. TBI is simply formulated as follows:

$T B I=(X-M) /(X+M)$
Where:

TBI = Trade balance index for Indonesian crab products

$\mathrm{X}=$ Value of export of Indonesian crab products

$\mathrm{M}=$ Import value of Indonesian crab products

TBI is an indicator to find out the pattern of trade and the stage of industrialization of a commodity based on the period, so that the performance of the commodity can be measured. The index value varies from -1 to +1 . In extreme terms, TBI is equal to -1 if a country only imports, and vice versa, TBI is equal to +1 if a country exports and imports commodities simultaneously. A country is a net importer of certain products if the TBI value is negative, and as a net exporter if the TBI value is positive.

According to the Ministry of Trade in (Lubis, 2013) specifically TBI will identify the growth rate of a product in trade into the following 5 stages:

- The introduction stage, if the TBI value is between -1 and -0.50. A product can be introduced into a country through imports, domestic consumption develops slowly and domestic products are still simple.

- Import substitution stage, if the TBI value is between -0.50 to 0.00 . Domestic products began to replace imported goods, the value of imports began to decrease, exports began to increase.

- Growth stage, if the TBI value is between 0.01 and 0.80 . at this stage export competition becomes tighter.

- Maturity stage, if the TBI value is between 0.81 to 1.00 . at this stage exports have high competitiveness.

\section{RESULTS AND DISCUSSION}

The main exporting country is the export of product processed crab in cans (HS 160510), are China, Indonesia and Philippines. As for frozen crab products (HS 030614), are Canada, Russia and China. Indonesia is not in the top 3 frozen export crab countries; this is because the Indonesian processing industry already has a market share of $90 \%$ of processed product exports. Table 2 is the biggest crab export country in 2017 (Uncomtrade, 2019). 
Table 2. Top three crabs export countries in 2017

\begin{tabular}{lc|lc}
\hline \multicolumn{2}{l}{ Processed crab in cans-(HS 160510) } & \multicolumn{2}{l}{ Frozen crab (HS 030614), } \\
\hline Countries & Value (USD) & Countries & Value (USD) \\
China & $736,999,612$ & Canada & $1,017,672,232$ \\
Indonesia & $197,634,344$ & Russia & $556,322,407$ \\
Vietnam & $68,909,168$ & China & $317,335,415$ \\
\hline
\end{tabular}

\section{Balance of trade in Indonesian crab products}

The trade balance includes exports and imports of goods. If the export of goods is greater than the import of goods, then the trade balance surplus is said to occur. Conversely, if the import of goods is greater than the export of goods, then this situation is called the trade balance deficit (Basri, 2010). Since 2016 until 2018 the trade balance of crab products has fluctuated as illustrated in Table 3 (Uncomtrade, 2019).

Table 3. Export and Import Volume of crab products

\begin{tabular}{llrrr}
\hline HS Code & Information & \multicolumn{2}{c}{ Volume $(\mathrm{Kg})$} & \\
\hline \multirow{3}{*}{160510} & & \multicolumn{1}{c}{2016} & \multicolumn{1}{c}{2017} & \multicolumn{1}{c}{. } \\
\cline { 3 - 5 } & Export & $17,039,194$ & $10,324,000$ & $13,546,894$ \\
030614 & Import & 419,697 & 102,800 & 50,040 \\
& Export & $3,296,040$ & $2,210,187$ & $1,249,786$ \\
& Import & $4,602,253$ & $4,631,431$ & $5,516,558$
\end{tabular}

Source: UN Comtrade, 2019

From Table 3, it shows that the number of exports of processed crab in cans products increased in 2018 and is greater than frozen products, and also the number of imported processed crab in cans products is smaller than frozen. Decreasing frozen crab exports and Increasing imports of frozen crab products indicate that consumption of frozen crabs in Indonesia is increasing.
Trade position of processed crab in cans products and frozen Indonesian crabs

Indonesian crab processed products crab in cans tend to be exporters. While frozen crab products tend to be importers. The TBI value of frozen crab products tends to decrease from 2009. It can be seen in Figure 2.

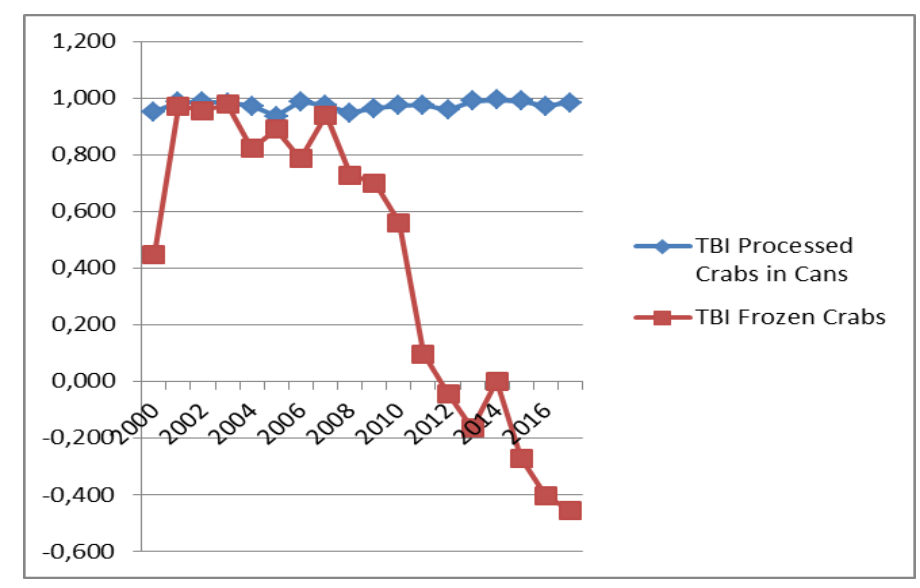

Figure 2. Trade Balance Index (TBI) of Indonesian crab products 
Indonesian Frozen and Processed Crab Export Performance and Competitiveness Analysis

Figure 2 show about value TBI of crab in cans product and frozen crab product. The value of crab in cans is stable around 0.9 , indicate Indonesia in maturity stage and this stage exports have high competitiveness.

\section{Comparative Advantage of Indonesian crabs}

\section{Comparative advantages Indonesian processed crab in cans products (HS 160510)}

Countries with the highest export value of HS 160510 in 2017 are Indonesia, China and Vietnam. The NRCA value of Indonesian processed crab in cans products tends to be larger than other countries. The following is the calculation of the NRCA value of Indonesian crab processed products shown in Figure 3.

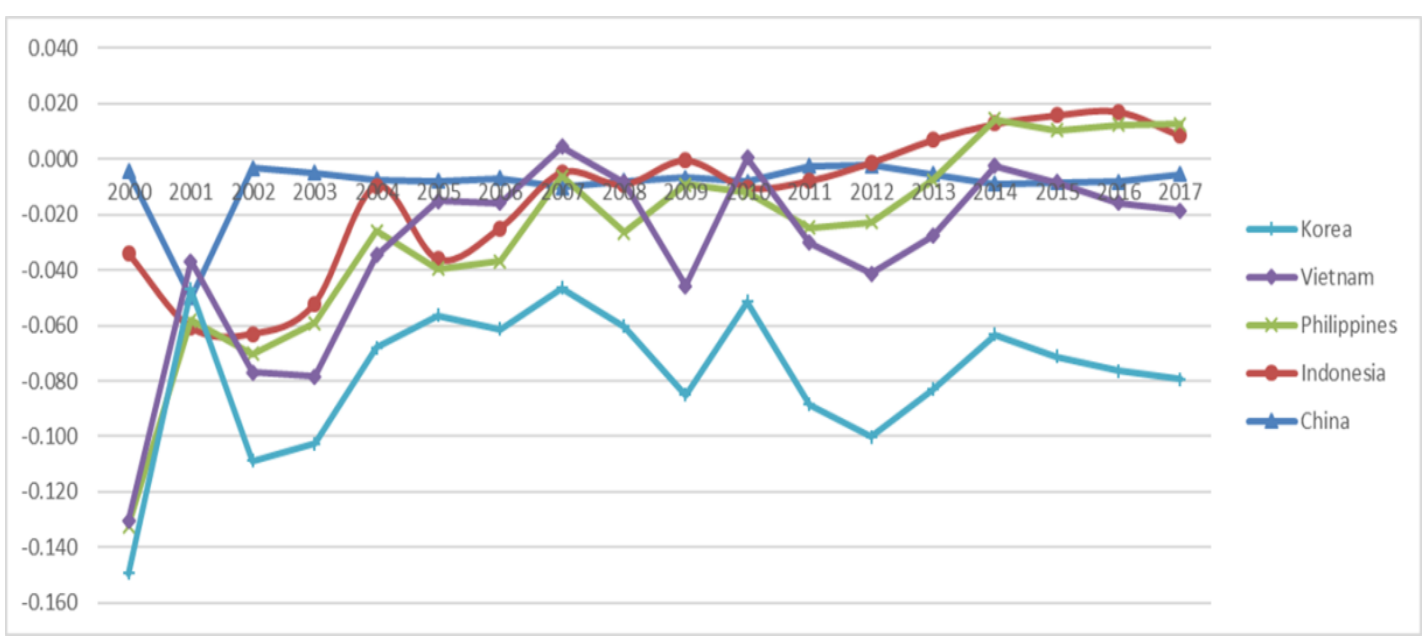

Figure 3. NRCA value of Indonesian processed crab in cans products

The NRCA value of Indonesian processed crab in cans products tends to increase and above zero (0), indicating that processed crab in cans products have comparative advantages. However, the value of the NRCA of Indonesian crabs in Figure 3 is still low and needs to be increased again with more sales and quality. Quality improvement will increase the selling price per kilogram of processed crabs. Thus, the price offered is higher and the export value is higher. The increase in export value will increase the comparative advantage of these commodities. Indonesia's opportunity to improve the comparative advantage of crabs is very large because Indonesia still has not maximized the management of crabs. Distribution of crab product as shown in figure 4 :

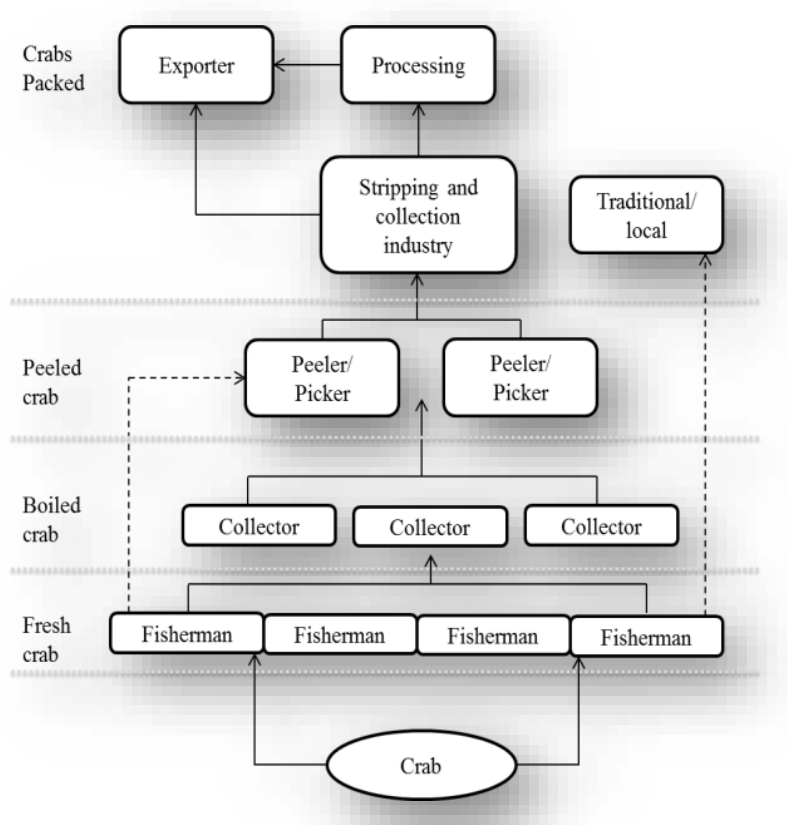

Figure 4. Distribution of crab product Source. Minister of Marine and Fisheries of The Republic of Indonesia, 2015 
Table 4. CEP value of Indonesian crab processed products

\begin{tabular}{cccccc}
\hline Year & China & Indonesia & Philippines & Vietnam & Korea \\
\hline 2013 & $-0,057$ & 1,151 & 0,697 & 0,307 & $-1,112$ \\
2014 & $-0,160$ & 1,431 & 1,145 & 0,368 & $-1,274$ \\
2015 & $-0,147$ & 1,539 & 0,942 & 0,284 & $-1,310$ \\
2016 & $-0,138$ & 1,555 & 0,953 & $-0,034$ & $-1,253$ \\
2017 & $-0,055$ & 1,225 & 1,193 & $-0,144$ & $-1,276$ \\
\hline
\end{tabular}

From the table above, showing the CEP value of Indonesia from 2013-2017 which is above 1, it can be explained that Indonesia is a country that is specialized in managing the production and export of processed crab products.

\section{Comparative advantages Indonesian frozen crab products (HS 030614).}

The NRCA value of China tends to be more stable compared to Indonesia. The NRCA value of Indonesia's frozen crabs tends to decline from 2014. The decline in frozen crab exports is due to the import value of frozen crabs higher than the value of exports in recent years. The NRCA value of frozen crabs can be seen in Figure 5.

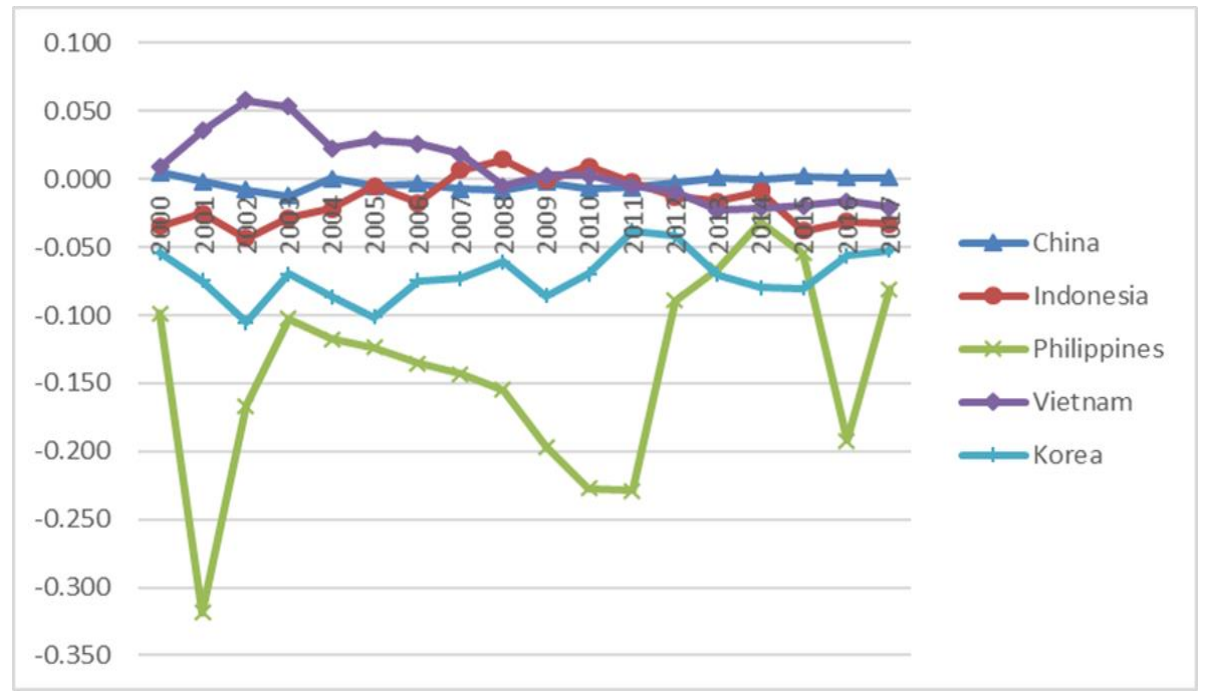

Figure 5.NRCA value of Indonesian frozen crab products

Figure 5 show about value NRCA of Indonesia frozen crab is minus from 2011. That indicates that Indonesia is less competitive in frozen crab products. but this must be considered because the consumption of frozen crabs in Indonesia is increasing, as evidenced by the higher import value each year. The specialization of frozen crab products shown in Table 5 .

This table show about value of CEP Indonesia more less than China and Vietnam. Indonesia's CEP value is very volatile. Indicates that Indonesia is less specialized in frozen crab products. 
Indonesian Frozen and Processed Crab Export Performance and Competitiveness Analysis

Table 5. CEP value of Indonesian frozen crab products

\begin{tabular}{llllll}
\hline Year & China & Indonesia & Philippines & Vietnam & Korea \\
\hline 2013 & 0,134 & 0,419 & $-0,656$ & 0,322 & $-1,489$ \\
2014 & 0,093 & 0,650 & 0,330 & 0,334 & $-1,758$ \\
2015 & 0,167 & $-0,169$ & $-0,364$ & 0,336 & $-1,771$ \\
2016 & 0,128 & 0,036 & $-4,293$ & 0,404 & $-1,065$ \\
2017 & 0,141 & $-0,014$ & $-1,116$ & 0,249 & $-0,961$ \\
\hline
\end{tabular}

\section{CONCLUSION}

The performance of trade in Indonesian crab commodities in international markets is seen through the trade balance and the Trade Balance Index. Based on the trade balance, the export growth of processed crab products per year has increased and conversely imports have decreased. While the frozen crab products exported by Indonesia have decreased. Furthermore, trade performance is seen from the position of trading in crab products using the TBI method. The results of the analysis state that of the two crab products, processed crabs are at the maturity stage. While frozen crabs are at the stage of growth.

The comparative advantage of crab commodities was analyzed using NRCA. The result of the analysis is that processed crabs in can have a comparative advantage of positive NRCA values of more than 0 . However, the NRCA value of frozen crab products in the past few years is minus. Supported by the CEP value, from the two products only processed crab products with values above 1 , which means Indonesia is specialized and more competitive in processed crab products.

\section{REFERENCES}

Basri and Munandar. 2010. Fundamentals of International Economics: Introduction and Application of Quantitative Methods. Jakarta (ID): Kencana Prenada Media Group

Bureau Central Statistic. 2019. Data Statistical export by commodity. https://www.bps.go.id/statictable/2014/09/ 08/1020/ekspor-kepiting-dan-kerangkerangan-menurut-negara-tujuan-utama2002-2015.html access on 11 march 2019.
Faridah, S. 2016. Analysis of Performance and Competitiveness of Exports of Indonesian Seaweed on the World Market. Journal of Bogor Agricultural Institute.

Lubis A. 2013. Competitiveness, trade performance, and the liberalization impact of forestry products. [internet]. [access on 11 march 2019]; 7(1): 37 - 53. Available: http://www.kemendag.go.id/files/pdf/2014 104/08/-1396957677.pdf

Marine and Fisheries Ministry.2017.Value Export

Main Commodity. (online),

https://kkp.go.id/wp-

content/uploads/2018/01/KKP-Dirjen-

PDSPKP-FMB-Kominfo-19-Januari-

2018.pdf, access on 10 March 2019

Supartono and Putri. 2015. Analysis of Rejection of Indonesian Rajungan (Portunus pelagicus) and Crab (Scylla serrata) Export Products in the United States of America 20022013. Proceedings of the Agro-Industry Seminar and FKPT-TPI National Workshop

UN COMTRADE. 2019. Statistical volume export-import by commodity 2016-2018, (internet) https://comtrade.un.org/data/ access on 10 march 2019.

UN COMTRADE. 2019. Statistical Year Book 2017 by commodity. (internet), https://comtrade.un.org/data/ access on 10 march 201 